\title{
Of Convergent Evolution and Legal Transplantation: The International Diffusion of the Duty of Care and the Business Judgment Rule*
}

\author{
CARsten GERnER-BEUERLE
}

\section{Introduction}

It is commonplace to acknowledge the considerable influence that AngloAmerican law has had on the development of corporate governance generally, and directors' duties specifically around the world. Directors are said to be "fiduciaries" who are entrusted with other people's money and, hence, should be subject to stringent duties of care, loyalty and good faith, which are often collectively referred to as "fiduciary duties". The characterization of directors as fiduciaries, and their duties as fiduciary duties, has its roots in the English law of equity and trust developed in the Court of Chancery. It was adopted early on by courts in the United States and is increasingly used by continental European commentators to emphasize the duty-bound position that directors occupy. It is therefore tempting to assume that fiduciary duties, in their present form, are legal transplants from the common law world introduced into civil law jurisdictions as a result of the rise of the Anglo-American corporate governance movement. ${ }^{1}$ On this view, the prevalence of the duties of care and loyalty in civil law jurisdictions is an instance of convergence in corporate law along the lines of Anglo-American law and, some would argue, a testament to the superiority of the common law in addressing the economic problems to which the corporate form gives rise. ${ }^{2}$

Christine Windbichler, I suspect, would disagree. In characteristically nuanced and perceptive fashion, she pointed out that a fiduciary understanding of the position of directors was inherent in the concept of a "corporate or-

\footnotetext{
* An extended and amended version of this paper has been published as: The Duty of Care and the Business Judgment Rule - A Case Study in Legal Transplants and Local Narratives, in Research Handbook on Comparative Corporate Governance (Afra Afsharipour \& Martin Gelter eds., 2020).

${ }^{1}$ Holger Fleischer, Legal Transplants in European Company Law: The Case of Fiduciary Duties, 2 ECFR 378, 382-5 (2005).

${ }^{2}$ Reinier H. Kraakman \& Henry Hansmann, The End of History for Corporate Law, 89 Geo. L.J. 439, 449-51 (2001).
} 
gan" under German law, and hence did not have to be imported from common law jurisdictions as a legal transplant. ${ }^{3}$ It is the goal of this contribution to her Festschrift to expand on this observation and investigate what exactly has been transplanted, if anything: terminology or (also) substance?

It is not possible to do justice to both of the two main types of directors' duties - the duty of care and the duty of loyalty - in this paper. I will focus on the former, which is, more so than the duty of loyalty, a common feature of any developed system of corporate law. It is one of the oldest legal institutions to impose constraints on the behaviour of corporate directors (and more generally persons acting in various commercial relationships). In an early form, it can be found in Roman law on the societas, which required each partner to exercise the care that they were accustomed to display in their own affairs in matters of business management. ${ }^{4}$ It is also a nearuniversal rule; it exists in one form or another in virtually every jurisdiction. ${ }^{5}$ This is unsurprising, given that the duty of care is concerned with a central economic problem in corporations, the managerial agency problem. It exists whenever management authority is delegated and has prompted regulatory intervention around the world, irrespective of legal tradition or form of market economy.

The duty of care has given rise to a "judicial offshoot" that qualifies the enforceability of breaches of the duty of care and has resulted, in particular in the United States, in a clear separation of a standard of conduct and a standard of review: the business judgment rule. The business judgment rule gives legal expression to the idea that questions of business judgment are best left to the honest decision of the directors. Courts are not well placed to substitute their own discretion for that of the directors, since they typi-

\footnotetext{
${ }^{3}$ Christine Windbichler, Gesellschaftsrecht $\$ 27 / 9$, in particular fn. 20 (24th ed. 2017).

${ }^{4}$ Reinhard Zimmermann, The Law of Obligations: Roman Foundations of the Civilian Tradition 461-65 (1996).

${ }^{5}$ For a detailed comparison of the duty of care in the United States and the United Kingdom, see David Kershaw, The Foundations of Anglo-American Corporate Fiduciary Law 135-281 (2018). For further selected common law jurisdictions, see Jennifer G. Hill, Evolving directors' duties in the common law world, in Research Handbook on Directors' Duties 3 (Adolfo Paolini ed., 2014). For European civil law countries, see Carsten GernerBenerle E Edmund-Philipp Schuster, Mapping Directors' Duties: The European Landscape, in Boards of Directors in European Companies 13, 14-23 (Hanne Birkmose, Mette Neville \& Karsten Engsig Sørensen eds., 2013). For China, see Guangdong Xu et al., Directors' Duties in China, 14 EBOR 57. For Japan, see Hideki Kanda \& Curtis J. Milhaupt, Re-Examining Legal Transplants: The Director's Fiduciary Duty in Japanese Corporate Law, 51 Am. J. Comp. L. 887. Other broad comparative studies include Bernard S. Black et al., Comparative Analysis on Legal Regulation of the Liability of Members of the Board of Directors and Executive Organs of Companies, ECGI - Law Working Paper Series 103/2008; Paul Davies et al. (eds.), Corporate Boards in Law and Practice (2013); and Andreas M. Fleckner E Klaus J. Hopt (eds.), Comparative Corporate Governance: A Functional and International Analysis (2013).
} 
cally lack the necessary expertise and act with the benefit of hindsight. ${ }^{6} \mathrm{Al}-$ lowing courts to fully review business decisions adopted in good faith and without a conflict of interest would therefore give rise to the risk of false positives: instances where courts might identify a breach of the duty, even though the decisions of directors, assessed from an ex-ante perspective under conditions of uncertainty about the future, were duty-compliant. Since this economic problem exists in all jurisdictions, legal systems can be expected to have developed solutions that restrict the liability of directors. ${ }^{7}$ One such solution is the business judgment rule, ${ }^{8}$ which has diffused increasingly widely over the last few decades and can now be found, for example, in eight European countries that all belong to the civil law tradition. ${ }^{9}$

Both the duty of care and the business judgment rule exhibit remarkable consistency across jurisdictions. Formulations of the two rules vary, of course, in numerous details, but the basic contours of the duty of care and the business judgment rule (where it has been adopted) are similar. Ostensibly, therefore, they are evidence of the convergence thesis mentioned above. ${ }^{10}$ However, two questions remain. First, it is important to note that convergence and transplantation are not the same. Convergence is often used without providing a precise definition of the term. The meaning of the corresponding concept in evolutionary biology makes the difference between convergence and transplantation clear (although legal scholars may, of course, opt for a broader definition). Convergent evolution in biology refers to a process whereby unrelated organisms independently evolve similar traits as a result of adaptation to similar environments. ${ }^{11}$ Convergence, in this sense, therefore, says nothing about the influence that a particular legal tradition had internationally, or the superiority of that legal tradition in

\footnotetext{
${ }^{6}$ An early statement to this effect can be found in Ellerman v. Chicago Junction Railways E Union Stock-Yards Co. 49 N.J. Eq. 217, 232 (N.J. Ch. 1891): "Questions of policy of management, of expediency of contracts or action, of adequacy of consideration not grossly disproportionate, of lawful appropriation of corporate funds to advance corporate interests, are left solely to the honest decision of the directors ... To hold otherwise would be to substitute the judgment and discretion of others in the place of those determined on by the scheme of incorporation." For an overview of the historical development of the business judgment rule, see Kershaw supra note 5, 68-92.

${ }^{7}$ It can be shown that restricting liability for breaches of the duty of care is efficient, see Holger Spamann, Monetary Liability for Breach of the Duty of Care?, 8 JLA 337.

${ }^{8}$ Functionally equivalent solutions exist, as we will see in section IV.

${ }^{9}$ These eight countries are Austria, the Czech Republic, Croatia, Germany, Greece, Portugal, Spain and Romania. See Luis Hernando Cebria, The Spanish and the European Codification of the Business Judgment Rule, 15 ECFR 41 (2018).

${ }^{10}$ Supra note 2 and accompanying text.

${ }^{11}$ C. Tristan Stayton, The definition, recognition, and interpretation of convergent evolution, and two new measures for quantifying and assessing the significance of convergence, 69 Evolution 2140, 2141 (2015).
} 
comparison with other traditions. The reference to directors as "fiduciaries" would not be an indication of substantive legal borrowing, but simply of an emerging common terminology denoting legal concepts that had evolved independently and endogenously, yet were similar, because they were perceived as appropriate responses to similar economic problems. Second, even where legal institutions are borrowed from Anglo-American law, as the business judgment rule, convergence, understood as not only formal borrowing, but substantive alignment of legal solutions, does not occur if the transplanted legal institution functions differently in the receiving state, for example because it is interpreted differently or complementary institutions operate differently.

In order to explore these questions, this paper traces the historical development of the duty of care and the standard of care across countries. It focuses on four jurisdictions representing, and having shaped, three influential legal traditions: the United States (and here in particular Delaware), the United Kingdom, France and Germany. Section II sketches the evolution of the duty of care as a core constraint on directorial discretion. Section III elaborates on the standard of care to which directors are held accountable. Section IV describes the operation of the Delaware business judgment rule and examines whether the German version of the rule, as well as functional substitutes that can be found in the UK and France, are comparable to the Delaware rule. Section V concludes.

\section{Origins of the duty of care}

The common law duty of care has its origins in $18^{\text {th }}$ and $19^{\text {th }}$ century trust law and the law of bailment, from which it was adapted to corporate directors. ${ }^{12}$ Early English case law concerning the duties of corporate directors emphasised that directors were "in the position of trustee" or "quasi trustees". ${ }^{13}$ As such, they were required "to use all the ordinary prudence that can be properly and legitimately expected from any person in the conduct of

${ }^{12}$ Kershaw, supra note 5, 229-63.

${ }^{13}$ Re Exchange Banking Co (Flitcroft's Case) (1882) 21 Ch. D. 519, 534-35. But see also In Re City Equitable Fire Insurance Company [1925] Ch. 407, 426, where Romer J. adopted a more nuanced view eschewing direct analogies: "It has sometimes been said that directors are trustees. If this means no more than that directors in the performance of their duties stand in a fiduciary relationship to the company, the statement is true enough. But if the statement is meant to be an indication by way of analogy of what those duties are, it appears to me to be wholly misleading. I can see but little resemblance between the duties of a director and the duties of a trustee of a will or of a marriage settlement. It is indeed impossible to describe the duty of directors in general terms, whether by way of analogy or otherwise." For a careful analysis of the extent to which courts relied on analogies to trust law and the law of bailment, see Kershaw, supra note 5, 230-35. 
the affairs of the world". ${ }^{14}$ In the development of the duty of care in the United States, it has been shown that the law of bailment was more influential than trust law, a difference that has been associated with differences in the conceptualization of companies incorporated by registration. In the United States, the general incorporation statutes of the $19^{\text {th }}$ century were intended to open up access to the corporate form and make it unnecessary to petition state legislatures for a corporate charter. Registered companies could therefore be seen as a continuation of chartered companies, and there was no question that both were the legal owners of the assets devoted to the business enterprise. In Britain, in contrast, incorporation by registration was introduced to remedy the defects to which the widespread use of so-called deed-of-settlement companies had given rise, which were based on partnership law and hence were not separate legal entities that owned the assets of the business. ${ }^{15}$ The law of bailment was a more natural analogy in the United States, since a bailee, just as a director, was entrusted with the management of assets owned by other persons, while there was an actual trustee in a deed-of-settlement company, who was the legal owner of the association's property. ${ }^{16}$ These conceptual differences had implications for the standard of care applicable to directors, ${ }^{17}$ but not the fact that directors, as fiduciaries akin to either bailees or trustees, were subject to a duty of care. In the early duty of care case Briggs v. Spaulding, for example, the US Supreme Court held that directors, "as mandataries ... are ... bound to apply ordinary skill and diligence". ${ }^{18}$

In its reliance on analogies with agents or bailees, ${ }^{19}$ the early approach in the United States resembles the origins of the duty of care in civil law countries. The first European piece of legislation to develop a general set of rules governing stock corporations and other business associations, the French Code de Commerce of 1807, described the directors as mandataries who were only responsible for carrying out their contractually agreed duties: "Les administrateurs ne sont responsables que de l'exécution $d u$ mandat qu'ils ont reçu." 20 The Code de Commerce applied not only in France, but also some western states of the former Holy Roman Empire from 1806-1813, the socalled Confederation of the Rhine. It influenced the first Germany-wide codification of stock corporation law, the General German Commercial

${ }^{14}$ Overend E Gurney v Gibb (1871-72) L.R. 5 H.L. 480, 494.

${ }^{15}$ Kershaw, supra note 5, 176, 233-35.

${ }^{16} I d$. at 234.

17 Early case law in the United States was pulled in the direction of a gross negligence standard, arguably informed by the bailment analogy, since the standard of care pursuant to the law of bailment was gross negligence if the bailee acted gratuitously. See the references $i d$. at $143-59,174-96$.

18141 U.S. 132, 148 (1891), quoting Spering's Appeal 71 Pa. 11, 21 (1872).

${ }^{19}$ Id.

${ }^{20}$ Code de Commerce, Art. 32. 
Code of 1861, and the corporate laws of other continental European states, for example Portugal and Spain. These jurisdictions drew on agency law to require directors to discharge their duties with appropriate care, but had nothing to say about duties not conferred on the directors as part of their mandate. ${ }^{21}$ Early European statutes, accordingly, focused only on the transgression of the mandate by a director or the failure to comply with the law and the articles, but did not describe the position of directors in terms of duties. They did not recognize obligations that were separate from contractually established obligations and existed by virtue of the appointment to a position of power, and hence did not regard directors as being subject to a general duty of care (or indeed a duty of loyalty ${ }^{22}$ ). ${ }^{23}$

The prevalent civil law approach changed over time, as commentators and policy makers came to realize that a formulation of the duty of care that focused on the position of directors within the corporate hierarchy, rather than their contractual obligations, was necessary to capture certain pathologies of the corporate form. ${ }^{24}$ For example, a sweeping reform of German stock corporation law of $1884,{ }^{25}$ which was adopted in response to widespread corporate misconduct that had led to the first major stock exchange crash in German history, replaced the contractual focus of the formulation of directorial behavioral expectations with a positional focus. The General Commercial Code, as revised in 1884, provided that, "in managing the corporation, the members of the management board have to exercise the care of a diligent businessman". ${ }^{26}$ The provision has remaind substantially the same

${ }^{21}$ For a contemporary comparative overview, see Achilles Renaud, Das Recht der Actiengesellschaften 538-39 (1863).

22 The narrow conceptualization of the obligations of directors proved particularly obstructive to the development of the duty of loyalty in civil law countries. Many continental European jurisdictions operated for a long time (and to some degree still operate) with fragmentary rules, rather than an all-encompassing behavioural standard, to address conflicts of interest, see Carsten Gerner-Beuerle E Michael Schillig, Comparative Company Law 508, 565-69, 574-75 (2019).

${ }^{23}$ See, e.g., Allgemeines Deutsches Handelsgesetzbuch 1861 (ADHGB) [General German Commercial Code], Art. 241(2), providing that "members of the management board who exceed the limits of their mandate or act in contravention of the provisions of this title [of the Commercial Code] or the articles of association are personally and jointly liable for the damage thus caused".

${ }^{24}$ See, for example, the criticism of the General German Commercial Code of 1861 by Renaud, supra note 21,537, who argued that the scope and content of the duties of directors should be determined by the law, articles, resolutions of the general meeting, and what was inherent in their position as a director.

${ }^{25}$ Gesetz, betreffend die Kommanditgesellschaften auf Aktien und die Aktiengesellschaften [Act Concerning Limited Partnerships by Shares and Joint Stock Corporations] of 18 July 1884, RGBl. 1884, p. 123.

26 ADHGB, Art. 241(2) (emphasis by author). The standard of the "diligent businessman" is translated from "ordentlicher Geschäftsmann". The same standard of care applied to members of the supervisory board, ADHGB, $\$ 226(1)$. 
since 1884, and the current Stock Corporation Act requires directors to "exercise the care of a diligent and conscientious manager in managing the company." ${ }^{27}$ A similar shift away from a contractual understanding of directors' duties occurred in other continental European systems at different times, for example in France in the 1940s. ${ }^{28}$ Some remnants of the tripartite reference to the director's mandate (contract), the articles of association, and corporate law as sources of directorial obligations is nevertheless still discernible in the formulation of directors' duties in some civil law jurisdictions. The relevant provision of the French Commercial Code, for example, bears little resemblance to the duty of care of Anglo-American provenance: "The directors ... shall be individually or jointly and severally liable to the company or third parties either for infringements of the laws or regulations applicable to public limited companies, or for breaches of the memorandum and articles of association, or for management mistakes.”29

\section{Standard of care}

In spite of the different genesis of the duty of care and certain remaining differences in the formulation of the codified duties, the standard of care across both common law and civil law countries is remarkably similar. Legal systems typically use variations of the "ordinary man" or "ordinary businessman" benchmark to describe the standard of care expected of directors. In the leading English duty of care case until the codification of directors' duties in 2006, City Equitable Fire Insurance Company, ${ }^{30}$ Romer J held that directors were expected to act with "reasonable care", which was "to be measured by the care an ordinary man might be expected to take in the circumstances on his own behalf". ${ }^{31}$ The English common law standard, thus,

${ }^{27}$ Aktiengesetz (AktG) 1965 [Stock Corporation Act 1965], BGBl. I, p. 1089, § 93(1). The slightly different formulation in comparison with the ADHGB of 1884, which includes the word "conscientious", was not intended to modify the applicable standard of care, see Marcus Lutter Der Aufsichtsrat im Wandel der Zeit - von seinen Anfängen bis heute, in Aktienrecht im Wandel II: Grundsatzfragen des Aktienrechts 389, 407 (Walter Bayer \& Mathias Habersack eds., 2007).

${ }^{28}$ Carsten Gerner-Beuerle, Philipp Paech E Edmund Schuster, Study on Directors' Duties and Liability, Annex: Directors' Duties and Liability in France, p. A304 (2013), available at http://personal.lse.ac.uk/schustee/2013-study-reports_en.pdf.

${ }^{29}$ Code de Commerce [French Commercial Code], Art L225-251. For another example, see the Belgian Companies Code, which, until very recently, referred to directors explicitly as mandataries who were responsible "de l'exécution du mandat qu'ils ont reçu et des fautes commises dans leur gestion", in addition to "d'infractions aux dispositions du présent code ou des statuts sociaux." Code des sociétés 1999 [Belgian Companies Code], Arts 527, 528. These provisions have now been superseded by the Companies Code of 2019.

${ }^{30}$ [1925] Ch. 407.

${ }^{31}$ Id. at 428. 
was ostensibly an objective standard. However, City Equitable infused this standard with subjective elements distilled from earlier case law. Importantly, Romer J stated that "[a] director need not exhibit in the performance of his duties a greater degree of skill than may reasonably be expected from a person of bis knowledge and experience." ${ }^{32}$ It was unclear how the reference to the defendant director's subjective attributes was to be reconciled with the objective benchmark and, in particular, whether lack of competence or experience was liable to reduce the standard of care below that of an ordinary businessman. ${ }^{33}$ The uncertainty was resolved in the 1990s with two High Court judgments that established a dual objective-subjective standard, which was later codified in section 174 of the Companies Act 2006. ${ }^{34}$ Pursuant to section 174, directors are required to "exercise reasonable care, skill and diligence", which is defined as "the care, skill and diligence that would be exercised by a reasonably diligent person with ... the general knowledge, skill and experience that may reasonably be expected of a person carrying out the functions carried out by the director in relation to the company, and ... the general knowledge, skill and experience that the director has." 35

Delaware law and many other common law and civil law jurisdictions have adopted a standard of conduct that closely conforms to the objective leg of the UK's dual standard. The Delaware Court of Chancery, in Re Walt Disney Co. Derivative Litigation, ${ }^{36}$ held that "[ $\left.t\right]$ he fiduciary duty of due care requires that directors of a Delaware corporation 'use that amount of care which ordinarily careful and prudent men would use in similar circumstances,' and 'consider all material information reasonably available' in making business decisions" ${ }^{37}$ There is little difference between this formulation and the "care of a diligent and conscientious manager" under German law. ${ }^{38}$ In both jurisdictions, it is undisputed that the standard of care is objective, but varies with the circumstances, including the type of company and industry, the financial situation of the company, general market conditions, and the director's role and responsibilities within the corporate hierarchy. Furthermore, the requirement to "consider all material information reasonably available" is almost identical to the expectation under the German Stock Corporation Act that directors act based on "appropriate information", ${ }^{39}$ which has

${ }^{32} I d$. (emphasis by author).

${ }^{33}$ For an overview of the discussion and references, see Gerner-Beuerle E Schillig, supra note 22, 477-78.

${ }^{34}$ Norman v Theodore Goddard [1992] B.C.C. 14; Re D'Jan of London Ltd [1993] B.C.C. 646.

${ }^{35}$ UK Companies Act 2006, s. 174(2).

36907 A.2d 693 (Del. Ch. 2005).

${ }^{37} \mathrm{Id}$. at 749.

${ }^{38} \mathrm{AktG}, \mathrm{J}$ 93(1), sentence 1.

${ }^{39} \mathrm{AktG}, \int \mathrm{S}$ 93(1), sentence 2. 
been held to mean that directors must avail themselves of all available information, provided the costs are not disproportionate to the benefits. ${ }^{40}$ As a final example from yet another legal tradition, we may consider the central provision of the French law on the public stock corporation concerning the liability of directors, which was already quoted above. ${ }^{41}$ According to this provision, directors are liable for so-called management mistakes, in addition to breaches of the law and the memorandum and articles of association. What constitutes a management mistake is measured against the benchmark of the care that can reasonably be expected from a "prudent and diligent manager". ${ }^{42}$ Again, the precise behavioural expectations that are derived from this standard depend on the circumstances of the case, in particular the director's role in the company and the type of company. ${ }^{43}$ Thus, in all four jurisdictions reviewed briefly in this section, the formulation of the standard of care is largely interchangeable, in spite of the fact that these jurisdictions represent three distinct legal traditions that embody distinct approaches to ordering the market economy. ${ }^{44}$ This does not mean, of course, that the operation of the duty of care is interchangeable. We turn to this point in the next section.

\section{Qualification of the duty of care by the business judgment rule}

While a formal business judgment rule does not exist in many jurisdictions, the economic problem that was mentioned above-the inefficiencies created by a full review of business judgments by a court with the benefit of hindsight and, possibly, without the necessary expertise and experience ${ }^{45}-$ has been addressed in some form by most legal systems. It is clear that courts were acutely aware of this problem early on in the development of the duty of care, as illustrated by the following quote from one of the leading English cases from the $19^{\text {th }}$ century, Overend E Gurney v Gibb: ${ }^{46}$

${ }^{40}$ Gerald Spindler, $₫ 93$ AktG, in Münchener Kommentar zum Aktiengesetz, vol. 2 para. 55 (Wulf Goette, Mathias Habersack \& Susanne Kalss eds., 5th ed. 2019).

${ }^{41}$ Supra, text to note 29.

${ }^{42}$ Cass. com., 30 March 2010 (Crédit Martiniquais), Revue des sociétés 2010, p. 304, note P. Le Cannu.

${ }^{43}$ Philippe Merle, Droit commercial: Sociétés commerciales para. 458 (22nd ed. 2018).

${ }^{44}$ Britain, the United States and many other common law countries are typically referred to as liberal market economies, Germany, Japan, Switzerland and other countries in the German and Scandinavian legal traditions as coordinated market economies, and several Mediterranean countries, including France, Italy and Spain, are regarded as occupying an ambiguous position, Peter A. Hall E David Soskice, An Introduction to Varieties of Capitalism, in Varieties of Capitalism: The Institutional Foundations of Comparative Advantage 1, 19-21 (Peter A. Hall \& David Soskice eds., 2001).

${ }^{45}$ Supra, text to notes 6-8.

${ }^{46}$ Overend \& Gurney v Gibb (1871-72) L.R. 5 H.L. 480, 494-95. 
I think it would be a very fatal error in the verdict of any Court of justice to attempt to measure ... the amount of prudence that ought to be exercised by the amount of prudence which the judge himself might think, under similar circumstances, he should have exercised. I think it extremely likely that many a judge, or many a person versed by long experience in the affairs of mankind, as conducted in the mercantile world, will know that there is a great deal more trust, a great deal more speculation, and a great deal more readiness to confide in the probabilities of things, with regard to success in mercantile transactions, than there is on the part of those whose habits of life are entirely of a different character. It would be extremely wrong to import into the consideration of the case of a person acting as a mercantile agent in the purchase of a business concern, those principles of extreme caution which might dictate the course of one who is not at all inclined to invest his property in any ventures of such a hazardous character.

English courts have not formalised the considerations expressed in the above excerpt and delineated the boundaries of a director's business judgment, within which the courts will only exercise limited review. However, implicitly, they apply two distinct standards of care that have the effect of shielding a director's good faith business decisions from judicial review. The first is a good faith standard that applies to the content of a director's decision. Directors must act in what they consider, in good faith, to be in the best interest of the company. ${ }^{47}$ In the absence of evidence of a director's actual state of mind, good faith is analyzed based on the reasons given for the challenged decision. While the case law is not entirely consistent and courts tend to ask whether a particular course of action was "reasonable", they also stress that the relevant test is subjective. It does not involve an assessment of whether the decision was, in the court's view, objectively in the best interest of the company. ${ }^{48}$ This implies that the test may be seen, more accurately, as a form of plausibility or rationality test. Courts will not second-guess a business decision that is supported by rational business reasons, in the sense of reasons that could have been regarded by at least some directors as suggesting that the decision was in the company's interest. ${ }^{49}$

${ }^{47}$ See, e.g., Re Smith E Fawcett [1942] Ch 304. The duty to act in the best interest of the company is now codified in s. 172 Companies Act 2006.

${ }^{48}$ The holding in Regentcrest plc $v$ Coben [2001] B.C.C. 494 at 513-14 is very clear: "The question is not whether, viewed objectively by the court, the particular act or omission which is challenged was in fact in the interests of the company; still less is the question whether the court, had it been in the position of the director at the relevant time, might have acted differently. Rather, the question is whether the director honestly believed that his act or omission was in the interests of the company. The issue is as to the director's state of mind. No doubt, where it is clear that the act or omission under challenge resulted in substantial detriment to the company, the director will have a harder task persuading the court that he honestly believed it to be in the company's interest; but that does not detract from the subjective nature of the test."

${ }^{49}$ The standard has, accordingly, also been called the "any reasonable director" standard. See Kershaw, supra note 5, at 47-58 for a careful and critical analysis of the terminology used by the courts and inconsistencies in the case law. 
The second standard is the one described in section III above, which is now laid down in section 174(2) Companies Act 2006: an ordinary due care standard that imposes heightened behavioural expectations on a director if that director has particular knowledge, skill or expertise. The duty of care pursuant to section 174 Companies Act 2006 and the duty to act bona fide in the best interest of the company perform complementary functions. The former focuses on the process of decision-making. In arriving at a decision, directors are required to exercise the care, skill and diligence that can be expected of a reasonably diligent person. The latter concerns the quality of the decision itself, which must be capable of promoting the success of the company..$^{50}$

This bifurcated standard is already discernible in Overend E Gurney. The case concerned the acquisition of a banking business that had initially been very successful, but, at the time of the purchase, had incurred heavy losses and was balance sheet insolvent. The House of Lords found that the purchase itself, while risky and, as the court put it, "imprudent", ${ }^{51}$ was not irrational. The directors had restructured the debts of the business and relied on its continuing good reputation in their expectation that the company would improve its finances and become profitable again. ${ }^{52}$ This was enough for the court to conclude that the directors had acted in good faith, which, in turn, prevented the court from questioning whether they had exercised sufficient "prudence". ${ }^{53}$ The court then outlined a second, more stringent standard of review. It explained that the directors were also under an obligation to inquire into "any circumstance or transaction which ought to have been inquired into by the persons making [the challenged] purchase" and ascertain "every fact that was to be ascertained" in the circumstances..$^{54}$ This is clearly a process-related inquiry that is to be distinguished from an assessment of the merits of a business decision. In Overend E Gurney, no due-process failures had been alleged by the complaint and the court, accordingly, rejected any liability of the defendant directors for the decision to purchase the business.

Subsequent cases have not always been similarly clear in their differentiation of the two standards..$^{55}$ Nevertheless, where directors were found liable, this was generally (albeit not always ${ }^{56}$ ) because they were not sufficiently

50 "Success of the company" is the formulation used in s. 172(1) Companies Act 2006.

${ }^{51}$ Overend E Gurney v Gibb (1871-72) L.R. 5 H.L. 480 at 493.

${ }^{52} I d$. at $493-94$.

${ }^{53}$ See the quote from Overend $\mathcal{E}$ Gurney, supra in the text after note 46.

54 (1871-72) L.R. 5 H.L. at 495.

55 This holds, in particular, for City Equitable, supra note 30 and accompanying text. See also Kershaw, supra note 5, at 257-63, for a discussion of the influence that City Equitable had on corporate law scholarship and policy debates in the UK before the duty of care was codified in 2006 (arguing that City Equitable sowed "dissonance and confusion about the scope of the care standard", $i d$. at 263).

${ }^{56}$ See Roberts v Froblich [2012] B.C.C. 407. 
well informed, ${ }^{57}$ unquestioningly and uncritically complied with instructions and accepted information given by a corporate insider who engaged in fraudulent activity ${ }^{58}$ had failed to ensure that internal reporting and control systems worked effectively, ${ }^{59}$ or had remained completely inactive. ${ }^{60}$ Furthermore, as has been pointed out in the literature, the process-related nature of the duty is evidenced by the fact that directors are less likely to be held liable if they take certain procedural precautions, such as obtaining expert advice. ${ }^{61}$

A more explicit delineation of an area of protected business judgement and a more formal distinction between a standard of conduct and a standard of review can be found in the United States. This chapter will focus on Delaware law, where the courts began to grapple with the problem of determining the standard of review applicable to business decisions in the 1920s. In a string of decisions, the Delaware courts established the rule that directors were presumed to exercise their business judgment bona fide and in the best interest of the company. ${ }^{62}$ Further, they held that the presumption did not apply if the directors were either interested in the challenged transaction $^{63}$ or the circumstances of the transaction (for example the price paid for the assets of a corporation) were "so manifestly unfair as to indicate fraud". ${ }^{64}$ The latter was the case if the directors' actions were "so unreasonable as to be removed entirely from the realm of the exercise of honest and sound business judgment." ${ }^{65}$ These decisions relied on older, non-Delaware (often New Jersey) precedents that had sketched an area of business dealings - typically characterized, as a minimum, by the absence of fraud or bad faith, illegality, and conflicts of interest - that was regarded to be beyond judicial control. ${ }^{66}$ Similar to the reasoning of the House of Lords in Over-

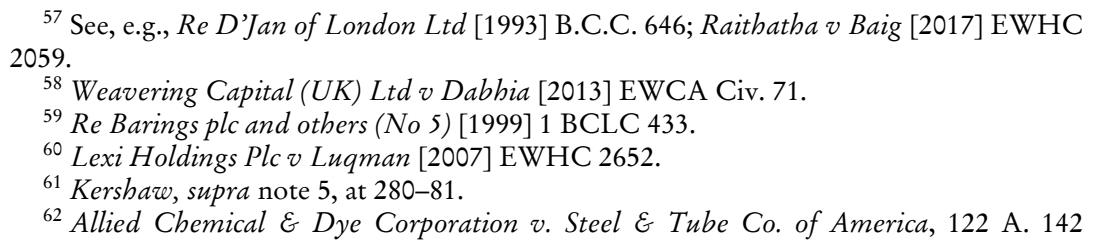
(Del. Ch. 1923) (speaking of "[a] presumption which the law would ordinarily accord in favor of the fairness of [the] official acts [of directors]" (i.e. their business judgment), $i d$. at 146).

${ }^{63} I d$. at 146.

${ }^{64}$ Robinson v. Pittsburgh Oil Refining Corporation, 126 A. 46, 48 (Del. Ch. 1924).

${ }^{65} \mathrm{Id}$. at 49.

${ }^{66}$ For example, Allied Chemical \& Dye Corporation v. Steel \& Tube Co. of America, 120 A. 486, 493 (Del. Ch. 1923), relied on the New Jersey case Hodge v. United States Steel Corp., 64 N.J. Eq. 807 (N.J. Ct. Err. \& App. 1903) (holding that "individual stockholders cannot question, in judicial proceedings, corporate acts of directors, if the same are within the powers of the corporation, and in furtherance of its purposes, are not unlawful or against good morals, are done in good faith and in the exercise of an honest judgment", 
end $\mathcal{E}$ Gurney, the rationale given for such judicial restraint was that intervening in "[q]uestions of policy of management", which were left to the honest decision of the directors, would amount to "substitut[ing] the judgment and discretion of others in the place of those determined on by the scheme of incorporation" ${ }^{67}$

In the first decades of its development, the Delaware approach was not yet known under the name "business judgment rule", and the precise contours of the rule were not yet well established. ${ }^{68}$ Two decisions of the Delaware Supreme Court from the first half of the 1980s gave the business judgment rule its modern form: Zapata Corp v. Maldonado ${ }^{69}$ and Aronson v. Lewis. ${ }^{70}$ In Aronson, the Supreme Court described the business judgement rule as "a presumption that in making a business decision the directors of a corporation acted on an informed basis, in good faith and in the honest belief that the action taken was in the best interests of the company". ${ }^{71}$ Furthermore, the protections of the business judgment rule "can only be claimed by disinterested directors ... [T] his means that directors can neither appear on both sides of a transaction nor expect to derive any personal financial benefit from it in the sense of self-dealing, as opposed to a benefit which devolves upon the corporation or all stockholders generally." 72 The burden is on the plaintiff to rebut the presumption, in which case the burden of proof shifts (generally ${ }^{73}$ ) to the defendant director to show the entire fairness of the challenged decision. ${ }^{74}$ On the other hand, if the three conditions - acting on an informed basis, in good faith, and without a conflict of interest-are met, the courts will not engage in a review of the quality of the business decision (with one very limited exception, the so-called waste claim or irrationality review $\left.{ }^{75}\right)$.

id. at 817-818, and quoting Ellerman v. Chicago Junction Railways \& Union Stock-Yards Co., 49 N.J. Eq. 217, 232 (N.J. Ch. 1891)).

${ }^{67}$ Ellerman, 49 N.J. Eq. at 232. A similar explanation is given by Hodge, 64 N.J. Eq. at 812.

${ }^{68}$ The diffusion of the term "business judgment rule" is traced by Kershaw, supra note 5, at 80-81 (identifying Nadler v. Betblehem Steel Corp. 154 A.2d 146 (Del. Ch. 1959), as the first case employing the term).

${ }^{69} 430$ A.2d 779 (Del. 1981).

70473 A.2d 805 (Del. 1984).

${ }^{71} I d$. at 812 .

${ }^{72} \mathrm{Id}$.

${ }^{73}$ Unless a conflict of interest has been "cleansed" pursuant to Del. Gen. Corp. Law, $\int 144$.

${ }^{74}$ In re Walt Disney Co. Derivative Litigation, 907 A.2d 693, 747 (Del. Ch. 2005).

${ }^{75}$ For a definition of waste, see In re Walt Disney Co. Derivative Litigation, 906 A.2d 27 (Del. 2006): "To recover on a claim of corporate waste, the plaintiffs must shoulder the burden of proving that the exchange was 'so one sided that no business person of ordinary, sound judgment could conclude that the corporation has received adequate consideration.' A claim of waste will arise only in the rare, 'unconscionable case where directors irrationally squander or give away corporate assets.' This onerous standard for waste is a corollary 
This basic operational framework of the business judgment rule has remained in place, although some of the conditions on which the presumption is based have shifted since Aronson. Importantly, while Aronson identified the applicable standard of care on which director liability was predicated as a gross negligence standard ${ }^{76}$ the duty-of-care limb of the presumption (that is, the requirement to act on an informed basis) has become all but irrelevant in the wake of the controversial Delaware Supreme Court decision in Smith $v$ Van Gorkom..$^{77}$ The Delaware courts now interpret gross negligence in the corporate context in a demanding manner that conflates rationality, bad faith and gross negligence. ${ }^{78}$ They define gross negligence as a "reckless indifference to or a deliberate disregard of the whole body of stockholders", ${ }^{79}$ involving actions "without the bounds of reason", ${ }^{80}$ or "a wide disparity between the process the directors used $\ldots$ and that which would have been rational." "11 Additionally, in order to counteract the risk that corporations incorporate elsewhere to evade the heightened risk of liability suggested by Van Gorkom, the Delaware legislature included a provision in the Delaware General Corporation Law enabling companies to exclude liability of a director for monetary damages for a breach of the duty of care, provided the director did not act in bad faith. ${ }^{82}$ Furthermore, subsequent decisions subsumed good faith under the duty of loyalty. Lack of good faith does not, by itself, establish liability for a breach of a fiduciary duty. ${ }^{83}$ Rather, bad faith is, in some circumstances, a necessary condition for liability, and where it is, liability may then arise as a result of a breach of the duty of loyalty. ${ }^{84} \mathrm{Im}$ portantly, this has been held to be the case where director oversight liability is concerned. ${ }^{85}$ As a consequence, under Delaware law, qualitatively different conduct gives rise to liability for director action on the one hand, and failure to act on the other. The leading case on oversight liability, Care-

of the proposition that where business judgment presumptions are applicable, the board's decision will be upheld unless it cannot be 'attributed to any rational business purpose."” $I d$. at 74 (footnotes omitted).

76473 A.2d at 812.

77488 A.2d 858 (Del. 1985).

${ }^{78}$ William T. Allen, Jack B. Jacobs \& Leo E. Strine, Realigning the Standard of Review of Director Due Care with Delaware Public Policy: A Critique of Van Gorkom and its Progeny as a Standard of Review Problem, 96 Nw. U. L. Rev. 449, 453 (2002).

79 Tomczak v. Morton Thiokol, Inc., 1990 WL 42607, at 12 (Del. Ch. 1990) (quoting Allaun v. Consolidated Oil Co., 147 A. 257, 261 (Del. Ch. 1929), and Gimbel v. Signal Companies, Inc., 316 A.2d 599, 615 (Del. Ch. 1974)); In re Walt Disney Co. Derivative Litigation, 907 A.2d 693, 750 (Del. Ch. 2005).

${ }^{80} I d$.

${ }^{81}$ Guttman v. Huang, 823 A.2d 492, 507 n. 39 (Del. Ch. 2003)

${ }^{82}$ Del. Gen. Corp. Law, \102(b)(7).

${ }^{83}$ Stone v. Ritter, 911 A.2d 362, 370 (Del. 2006).

${ }^{84}$ Id.

${ }^{85} \mathrm{Id}$. at 369. 
mark, ${ }^{86}$ held that lack of good faith as a necessary condition for director oversight liability required "a sustained or systematic failure of the board to exercise oversight - such as an utter failure to attempt to assure a reasonable information and reporting system exists" ${ }^{87}$ This is, as the Court of Chancery noted in Caremark, "a demanding test of liability", but it was thought to be in the economic interest of the shareholders. ${ }^{88}$

Disregarding the separate standard of review for oversight liability, Delaware and UK law operate largely in parallel, in spite of the absence of an explicit business judgement rule in the UK. The quality of a business decision is shielded from judicial review in both jurisdictions, unless a plaintiff can show bad faith. Lack of good faith will lead to liability under the further conditions of section 172 Companies Act 2006 in the UK and the entire fairness test in Delaware. The process of decision-making is ostensibly assessed against different standards of conduct: ordinary negligence (and heightened behavioural expectations in the case of special knowledge, skill or experience) in the UK and gross negligence, interpreted as recklessness or irrationality, in Delaware. However, it has been observed that British courts apply the objective limb of section 174(2) Companies Act 2006 so restrictively, and perform a skills adjustment pursuant to the subjective limb of the provision so reluctantly, that the standard of care is, in practice, close to the gross negligence standard of US jurisdictions. ${ }^{89}$

The deployment of a good faith standard to review the quality of business decisions is less common in civil law jurisdictions. The risk of liability is nevertheless generally not higher (and typically lower) than in the United States and Britain, mostly for procedural reasons..$^{90}$ A good example of the less well developed distinction between the process of decision-making and decision quality (and indeed between the duty of care and the duty of loyalty) is France, where the notion of the company's interest (l'intérêt social) guides the courts' assessment of liability for management mistakes. ${ }^{91}$ Directors are responsible for all acts or omissions that are contrary to the interests of the company. ${ }^{92}$ The infusion of considerations of the company's interest into the duty of care, something that, as we have seen, would be a matter for section 172 Companies Act 2006 in the UK, naturally invited the French

\footnotetext{
${ }^{86}$ In re Caremark Intern. Inc. Derivative Litigation, 698 A.2d 959 (Del. Ch. 1996).

${ }^{87} I d$. at 971.

${ }^{88} \mathrm{Id}$.

${ }^{89}$ Kershaw, supra note 5, at 281.

${ }^{90}$ Carsten Gerner-Beuerle E Edmund-Philipp Schuster, The Evolving Structure of Directors' Duties in Europe, 15 EBOR 191, 214-22 (2014).

${ }^{91}$ See supra, notes $29,42-43$ and accompanying text. On the conflation of the duties of care and loyalty in French corporate law, see also Gerner-Beuerle E Schillig, supra note 22, 574-75.

${ }^{92}$ Jean-Paul Valuet E Alain Lienhard, Code des Sociétés (34th ed. 2018), Com. Art. L225-251, Commentaire, I. Principe.
} 
courts to review not only the process of director decision-making, but also the quality of their decisions. Examples of management mistakes that gave rise to liability, accordingly, include transactions that were excessively risky, for example the ill-advised expansion of business operations without proper financing, ${ }^{93}$ the distribution of extraordinary dividends financed out of reserves during a time of contracting business operations, ${ }^{94}$ and the granting of excessive executive compensation. ${ }^{95}$

Notwithstanding these examples, courts in many civil law jurisdictions exhibit restraint in reviewing good-faith business decisions. ${ }^{96}$ Such restraint may be informal, in the sense of an acknowledgement that directors must be allowed to take risks inherent in economic activity and, hence, should benefit from an area of discretion that will not be fully reviewed by the courts, ${ }^{97}$ or formalised as a rule modelled after the Delaware business judgment rule. As mentioned, the latter approach is increasingly common, and business judgment rules similar to the Delaware rule can now be found in eight Member States of the EU belonging to the civil law tradition..$^{98}$ Similar to Delaware law, the continental European variants of the business judgment rule apply if several threshold conditions are satisfied, which typically include the requirement that the challenged business decision was based on appropriate information, there was no conflict of interest, and the defendant director reasonably believed that the decision was in the best interest of the company. ${ }^{99}$

In the following paragraphs, I will focus on the German version of the business judgment rule in more detail, which was the first such rule to be adopted in Europe in 2005. ${ }^{100}$ The rule is laid down in $\ 93(1)$, second sentence Stock Corporation Act. It applies if the following threshold conditions are met: (1) The defendant director must have acted in the best interest of the company ${ }^{101}$ and (2) the decision was based on appropriate informa-

${ }^{93}$ Cass. com., 3 January 1995 (Nasa Electronique), Bull. Joly Sociétés 1995, p. 432, note A. Couret.

${ }_{94}$ Cass. com., 25 October 2011 (Sté Sorim), Bull. Joly Sociétés 2012, p. 243, note D. Poracchia.

${ }^{95}$ CA Rennes, 13 December 1995, Droit des sociétés 1996, n 195, note Y. Chaput.

${ }^{96}$ For a more detailed discussion, including references, see Gerner-Beuerle \& Schuster, supra note $90,205-6$.

97 Id. at 205.

${ }^{98}$ Supra note 9.

${ }^{99}$ See Gerner-Benerle E Schuster, supra note 90, at 205, for references.

${ }^{100}$ Gesetz zur Unternehmensintegrität und Modernisierung des Anfechtungsrechts (UMAG) [Law on Corporate Integrity and Modernization of the Action of Annulment] of 22 September 2005, BGBl I 2005, p. 2802, Art. 1, no. 1a. The codified business judgment rule, in turn, is based on a decision of the Bundesgerichtshof [Federal Court of Justice] of 1997, BGHZ 135, 244 (ARAG/Garmenbeck), which adopted principles resembling the business judgment rule.

${ }^{101}$ Business decisions are in the best interest of the company if they "further the longrun profitability and competitiveness of the company and its products or services", BT- 
tion. ${ }^{102}$ Furthermore, even though not explicitly mentioned, because it was considered to be self-evident, challenged conduct is only protected by the business judgment rule if (3) it is not tainted by bad faith and (4) there is no conflict of interest. ${ }^{103}$ The director bears the burden of proof, since the general allocation of the burden of proof pursuant to $\$ 93(2)$, sentence 2 also applies to the threshold conditions.

On a cursory reading, the German business judgment rule follows closely its Delaware counterpart. The three prerequisites of the Delaware business judgment rule-duty of care, loyalty, and good faith-are all present. In two respects, the German version is more stringent (from the perspective of the director): In addition to the three conditions just mentioned, a court will assess whether the director acted in the best interest of the company. Furthermore, the burden of proof is on the director, whereas the plaintiff has to rebut the "presumptions" of the business judgment rule in Delaware. In two other respects, however, it is more lenient: The business judgment rule applies if the defendant director could "reasonable assume" that the threshold conditions of the rule were satisfied. Thus, the law does not provide for a negligence or gross negligence standard, but asks whether the director's subjective assessment was reasonable in light of the circumstances of the case. ${ }^{104}$ Second, if the conduct of a director is protected by the German business judgment rule, it will not be reviewed any further by the courts. In this

Drs. 15/5092, p. 11. It is noteworthy that the German legislator emphasises the "long-run profitability" of the company. This formulation could be interpreted as an expression of a more pluralistic approach to corporate governance, for which Germany is indeed often held out as an example. However, arguably, this is a simplistic view. The long-run profitability of the company is commonly regarded as the ultimate goal of corporate decisionmaking, irrespective of legal tradition or jurisdiction, see, for example, Paramount Communications, Inc. v. Time, Inc., 571 A.2d 1140 (Del. 1989) (holding that "absent a limited set of circumstances ..., a board of directors, while always required to act in an informed manner, is not under any per se duty to maximize shareholder value in the short term, even in the context of a takeover", $i d$. at 1150); UK Corporate Governance Code 2018, Principle A (stipulating that it is the role of the board of directors "to promote the long-term sustainable success of the company, generating value for shareholders and contributing to wider society"). Whether the definition of "corporate interest" in the legislative memorandum accompanying the German amendments of 2005 can be taken to imply that decisions that favour the interests of the shareholders in the short run at the expense of the employees, clients, or societal interests, or investments that are highly profitable in the short run, but put the long-run development of the company at risk, are not protected by the business judgment rule is, ultimately, a function of how the law is applied by the courts and regulators.

${ }^{102}$ What is appropriate depends on the available time, potential market pressures, the importance of the decision for the company, and generally accepted views of what constitutes good managerial practice, BT-Drs. 15/5092, p. 12.

${ }^{103} \mathrm{Id}$., at 11 .

${ }^{104}$ For example, the assessment is unreasonable where a director "misjudges the risks associated with a managerial decision in an entirely irresponsible way”, id. 
sense, the presumption of compliance with the duty of care that is established by the rule is therefore non-rebuttable. In the US, on the other hand, courts will engage in a limited substantive review of well-informed business decisions adopted in good faith and without a conflict of interest and inquire whether a decision was "irrational" or constituted a "waste of corporate assets". ${ }^{105}$ In summary, while differences exist between the German and Delaware business judgement rules, it is difficult to hold that one is clearly more protective than the other.

However, an analysis not only of the codified German rule, but also its application by the courts, casts doubt on this preliminary conclusion. This can best be shown by examining the approach in both jurisdictions to excessive risk-taking, which was thrown into sharp relief by the global financial crisis. Two decisions of the Delaware Court of Chancery, In re Citigroup Inc. Shareholder Derivative Litigation ${ }^{106}$ and In re Goldman Sachs Group, Inc. Shareholder Litigation, ${ }^{107}$ provide a clear illustration of the extent of the protection afforded by the business judgment rule under a consistent application of the Caremark standard. In Citigroup, the court observed: ${ }^{108}$

Citigroup was in the business of taking on and managing investment and other business risks. To impose oversight liability on directors for failure to monitor "excessive" risk would involve courts in conducting hindsight evaluations of decisions at the heart of the business judgment of directors. Oversight duties under Delaware law are not designed to subject directors, even expert directors, to personal liability for failure to predict the future and to properly evaluate business risk.

[I]t is tempting in a case with such staggering losses for one to think that they could have made the "right" decision if they had been in the directors' position. This temptation, however, is one of the reasons for the presumption against an objective review of business decisions by judges, a presumption that is no less applicable when the losses to the Company are large.

This approach is diametrically opposed to the treatment of the problem of excessive risk-taking in Germany. The case that discusses the problem in greatest detail, a decision of the Higher Regional Court Düsseldorf from $2009, I K B$, concerned the near-insolvency of a German lender that focussed on the provision of loans to medium-sized enterprises, IKB Deutsche Industriebank. ${ }^{109}$ Among other reasons, the Higher Regional Court Düsseldorf held that the "knowing" acceptance of "excessive risks"110 led to a

105 Supra, note 75 and accompanying text.

106964 A.2d 106 (Del. Ch. 2009).

1072011 WL 4826104 (Del. Ch. 2011).

108964 A.2d at 131. The reasoning in Goldman Sachs was similar.

${ }^{109}$ Oberlandesgericht [Higher Regional Court] Düsseldorf, decision of 9 December 2009, 6 W 45/09, BeckRS 2010, 532.

${ }^{110} I d$. at II 2 b) bb): “[I] it is reasonable to assume that the respondent's management board violated its duties grossly because the board did not act on the basis of sufficient in- 
breach of duties, because "[n]o management board acts in compliance with the duty of care if they take risks that will render the company insolvent if they materialise" and relate to "foreign, largely unknown and ultimately uncontrollable securities". ${ }^{111}$ Of course, there are a number of relevant factual differences between IKB on the one hand and Citigroup and Goldman Sachs on the other. However, the different legal qualification of risk-taking in the two jurisdictions is striking. It is also worth emphasizing that the difference in outcome in the three cases is not a function of modifications to the Delaware business judgment rule that were implemented in the process of transplantation of the rule into German law, ${ }^{112}$ but a different understanding of the role of the courts in evaluating and limiting risk-taking. ${ }^{113}$

\section{Conclusion}

Even though directors are frequently referred to as fiduciaries not only in common law countries, but also in civil law jurisdictions, the international diffusion of the duty of care is driven less by legal transplantation, and more by what could be called convergent evolution, to borrow a term from evolutionary biology. Countries from different legal families drew on distinct legal sources, ranging from trust law to the law of bailment and agency law, to develop responses to common economic problems within business associations. While they remain, at least to some extent, true to their distinct legal origins, the duties of care of the countries surveyed here have converged independently on a virtually identical, largely objective standard of care under the impression of the growth and increasing professionalization of the management of corporations in the late nineteenth and twentieth centuries. The use of different legal concepts to achieve similar outcomes is particularly evident in the approach of the courts to the review of good-faith business decisions. All jurisdictions acknowledge that a full review of all business decisions, including those made in good faith and without a conflict of interest, would be undesirable. However, while US states rely on a formal delimitation of reviewable versus non-reviewable matters (the business

formation and knowingly took excessive risks, in particular concentration risks.” Translation from Gerner-Benerle \& Schillig, supra note 22, at 517.

${ }^{111} I d$. at II 2 b) bb) bbb). Translation from Gerner-Benerle \& Schillig, supra note 22, at 518.

112 The different outcome is not related to any of the legal differences in the formulation of the German and Delaware business judgment rules identified supra, text to notes 104105, but to elements identical in the two jurisdictions: the fact that the business judgment rule does not protect conduct in violation of the law or the articles or carried out in bad faith.

${ }^{113}$ In the publication referred to supra, note *, I discuss a possible explanation for the different approaches. 
judgment rule), many European jurisdictions, such as the United Kingdom and France, follow a more informal strategy that advocates judicial restraint and a certain degree of deference to managerial decision-making. Paradoxically, in the one case discussed here where deliberate legal borrowing took place, the transplantation of the American business judgment rule into German law, courts in Delaware and Germany expressed markedly different views on how the borrowed institution should operate in the context of entrepreneurial risk-taking. Convergence in corporate governance, therefore, is certainly not an unambivalent, unidirectional process from common law to civil law countries, as some commentators would have it. Legal traditions matter, and so do idiosyncratic attitudes towards risk-taking, and perhaps other matters of corporate management. 